UDC $141.319 .8(043.5)$

\title{
Fedir Kyryliuk
}

Dr. of Ph. S., Prof., Prof. of Department of Political Science, Taras Schevchenko Kyiv National University,

e-mail:politia@i.ua

\section{Viktor Melnyk}

MA in Political Science in Taras Schevchenko Kyiv National University,

Lecturer of the Department of Philosophy and Social Sciences in Vinnintsya National Medical University named after Mykola Pirogov,

e-mail: Melnyk1996ethnol0gy@gmail. com

\section{HUMAN AND CITIZENSHIP IN THE CONTEXT OF PARADIGMAL POLITICAL SCIENCE MEASUREMENT}

\begin{abstract}
The critical analis of the centennial stage of the institutionalization of political science makes it possible to draw a paradoxical conclusion - political science is the science of debate and about debate. This is explained not only by the complexity of the methodological use of political science principles or by its poor integration in the subject area of other social (or behavioral) sciences. The main problems of political science are terminological uncertainty and methodological Abstraction. Each new approach in political science really can completely change the essence of its theoretical construction.

By introducing the term "Civil Political Science" into broad terms, the authors hope to make a step towards the structural determinacy of political science and give it a solid foundation - the problem of a person as a citizen. Civic political science is intended to improve political science, to arrive from the destructive influence of etatism, which is only masked by ideological stamps and reduces the very idea of the state (as an organism at the same time social, legal, created by a citizen-man for a citizen-man). Applying for the new principles of civil political science, the authors hope to begin the process of "deetatization" of political science in order to serve the true interests of the state - the interests of citizenship. It should not be forgotten that only citizens determine and produce statehood by the fact of their existence.

Man as a citizen was formed in the process of human transition from the wild stage of existence to settled life. The struggle of instincts of physical against moral feelings was accompanied by the whole process of political evolution of communities - from the primitive order to the present day. It did not pass the institute of citizenship, which was largely intended to reconcile the instinctive nature of man as a biosocial being (let us recall the patriarchal definition of Roman law). Consequently, the reconciliation of morality and physical nature within a person should be recognized as the prevailing tendency of civil political science.
\end{abstract}

Key-words: Civil Political Science, anthropos, citizenship, etatism, state, anthropology. 


\section{УДК $141.319 .8(043.5)$}

\section{Кирилюк Федір Михайлович}

Доктор філософських наук, професор кафедри політології, Київський національний університет імені Тараса Шевченка

e-mail: politia@i.ua

\section{Мельник Віктор Мечеславович}

Магістр кафедри політології, Київський національний університет імені Тараса Шевченка, асистент кафедри філософії та суспільних наук, Вінницький національний медичний університет ім. М. І. Пирогова

e-mail: Melnyk1996ethnol0gy@gmail.com

\section{ЛЮДИНА І ГРОМАДЯНСТВО В КОНТЕКСТІ ПАРАДИГМАЛЬНОГО ВИМІРУ ПОЛІТИЧНОЇ НАУКИ}

\section{Резюме}

Критична оцінка столітнього етапу інституціоналізації політичної науки дозволяє зробити парадоксальний висновок-політологія є наукою дискусій. Це пояснюється не лише складністю методичного використання політологічних принципів або її поганою інтеграцією в предметній сфері інших соціальних (чи поведінкових наук). Головні проблеми політології-термінологічна невизначеність та методологічна абстрактність. Кожен новий підхід у політології здатен повністю змінити сутність її теоретичної конструкції.

Впроваджуючи в широкий обіг термін «громадянська політології», автори сподіваються зробити крок до структурної визначеності політології та дати їй міцне підгрунтя - проблему людини як громадянина. Громадянська політологія покликана оздоровити політичну науку, вивести з-під згубного впливу етатизму, що лише маскується ідеологічними штампами і нівелює саму ідею держави (як організму одночасно соціального, правового, створеного людиноюгромадянином для людини-громадянина). Застосовуючи нові принципи громадянської політології, автори сподіваються розпочати процес «роздержавлення» політичної науки заради того, щоб вона слугувала істинним інтересам державності-інтересам громадянства. Не слід забувати, що саме громадяни зумовлюють і продукують державність фактом свого існування.

Людина як громадянин формувалась в процесі переходу людини від дикої стадії існування до осілого життя. Боротьба інстинктів фізичних проти моральних почуттів супроводжувала весь процес політичної еволюції спільнот - від первісного ладу і до сьогодні. Вона не оминула інститут громадянства, що значною мірою був покликане примирити інстинктивну природу людини як біосоціальної істоти (згадаймо патріархальне визначення римського права). Отже, примирення моралі та фізичної природи всередині людини слід визнати пануючою тенденцією громадянської політології.

Ключові слова: громадянська політологія, людина, громадянство, етатизм, держава, антропологія.

\section{1. Ветуп}

Криза політології. Політична наука сьогодні відображає загальні тенденції культурноцивілізаційного розвитку кожної окремо взятої держави або кожного окремо взятого народу. Наше твердження безумовно стосується будь-якої гуманітарної науки. Однак, політологія, як інтеграчія одночасно багатьох дисииплін і методів у сфері осмислення феномену «політичного», з притаманним їй історизмом, філософським базисом та надбудовою у формі традичій 
i теорій менеджменту, напевно найбільше відображає національний менталітет спільноти. Коли ми споглядаємо виступ політолога, то завжди звертаємо увагу на певний елемент традиційності, що єднає підходи, висновки, навіть професійний лексикон у вчених з різним громадянством. Історичні умови, реалії перманентного державотворення і ступінь цивілізаційної близькості чи віддаленості, давно вже розчленували політичну науку на багато самостійних дисциплін, що розвиваються відокремлено - в залежності від внутрішньої чи зовнішньої політики держави. Отже, політологія поступово перетворюється в науку детерміновану державою. Навіть 3 чисто етноцентричної точки зору політична наука сьогодні стоїть на сторожі інтересів кожного окремого державного організму. Ніхто ж не заперечуватиме, що в Російській Федерації, США чи Китаї сьогодні політологія сприймається, викладається, практикується абсолютно порізному (згаданий нами на початку тенденційни фактор культурно-цивілізаційного розвитку!). Однак, у всіх випадках геолокації політичної науки (навіть найвіддаленіших), вона об'єднана одним єдиним стержнем- етатизмом.

Державоцентризм безумовно не $є$ поганою стороною для науки. Все-таки будь-яка наука, в тому числі соціальна чи гуманітарна, зобов'язана працювати на державу та на державність. Тим паче це явище слід вважати позитивним, якщо воно залишається тим містком, що зберігає певну видимість універсальності для політології. Однак, тут ми вступаємо в цікаву і подекуди навіть ризиковану термінологічну дискусію: що ж слід розуміти під поняттями «держава» $\mathrm{i}$ «державність»? Чи можемо ми сприймати ці поняття універсально? Чи існують в середині наведених термінів відвічно діючі фактори культурно-цивілізаційної диференціації? Хто сказав, що «державність» не $\epsilon$ синонімом слів «громадяни», «народ», «нація»? Останнє твердження тим більше є важливим, оскільки наукові дослідження Ентоні Сміта вже давно довели існування та успішне функціонування такої моделі як «держава-нація». Сам же Ентоні Сміт вбачає головну лінію політичного розвитку світу в XXI столітті у боротьбі між «державами-націями» i «транснаціональною глобалізацією».

Отож, сто років визрівання, народження, інституціоналізації, впровадження в системи вищої освіти та навіть державного управління, привели нас до парадоксального висновку. Незважаючи ні на що, політологія в своїй основі залишається сьогодні наукою (чи навіть науковим комплексом) дискусійною. Це пояснюється відсутністю сталої (тобто не піддаванню сумнівам та дискусіям) та чіткої термінології, методології і постійним змінам в теоретичній структурі.

\section{2. Методи дослідження}

Методологічну основу дослідження складають культурно-історичний, соціокультурний та компаративний підходи у їх діалектичному зв'язку, а також методи культурно-семантичного аналізу, історизму та ін. На підставі компаративного аналізу виокремлюються окремі складові досліджуваних парадигм, досліджуються взаємозв'язки між ними залежно від сформованого в їхніх межах образу людини. При вирішенні більш конкретних завдань застосовувалися принципи єдності історичного і логічного, доповненості, відносності, аналогії тощо.

\section{3. Результати}

Ми зобов'язані структурувати політологію та дати їй нове міцніше підгрунтя. Політологію слід оздоровити, вивести з-під згубного впливу поза ідеологічного етатизму, що лише маскується ідеологічними штампами і нівелює саму ідею держави як організму соціального, правового, створеного людиною-громадянином для людини-громадянина. Ми мусимо розпочати процес роздержавлення політичної науки заради того, щоб вона слугувала справді інтересам державності-інтересам громадянства, що зумовлює цю державність самим фактом свого існування.

Політологічний етатизм у своїй основі передбачає посилену інституціоналізацію науки [14; 16; 32]. По суті, сьогодні політична наука спостерігає за тим, який же підхід переможе-інституціональний чи антропологічний. Останній завойовує все більше симпатій на заході, але над- 
звичайно поширений він також і в Китаї, Індії. Наприклад, у маленькому Королівстві Бутан (між Китаєм та Індією, в умовах постійної ядерної напруги між цим двома зовнішньополітичними гігантами) викладання політичної науки характеризується як «викладання практики управління державою, що орієнтована на створення атмосфери громадського щастя» [24].

Антропологічний підхід і політична антропологія. Китай, Південно-Східна, Південна Азія виявились найбільш підготованими для сприйняття і відтворення саме антропологічного підходу в політології. Саме в культурно-цивілізаційних умовах їхнього розвитку і слід шукати пояснення цього феномену. Філософія Сходу завжди диференціювала його від Заходу, але, наприклад, на думку Л. Гумільова, саме східна ідея пояснювати всі явища через їхнє сприйняття в людському вимірі, була взята на озброєння християнством і в сукупності з багатим спадком філософії давньогрецької до початку Середньовіччя перетворила колишню Римську імперію в сучасну нам Європу [8]. (Зазначимо також, що С. Соловйов у ряді своїх праць акцентував на східному походженні навіть давньогрецької філософії. Ця теза безумовно дискусійна. Однак, підкреслимо, що вся культура еллінізму була витвором «міксису» східної і західної ментальностей) [30].

Антропологічний підхід зароджувався у руслі процесу «гуманізації політичного» 19501960-х років. На нього поступово нашаровувалась також і політична антропологія, що вже в епоху тотальної етатизації та інституціоналізації політології протягом 1990-2000-х років, стала базисом всього антропологічного підходу. По суті, сприйняття політики через людський вимір сьогодні залишається важливою складовою наукового осмислення політичного завдяки політичній антропології. Певне сум'яття безумовно вносить відсутність термінологічної визначеності всередині політичної антропології. Однак, ми мусимо підкреслити, що універсальною формою, що відрізняє політичного антрополога від статиста чи інституціоналіста було, $\epsilon$ і буде відношення вченого до людини взагалі і до фактору людського в досліджуваному явищі зокрема. Якщо політолог (ширше-politicalscientists) спочатку звертає увагу на конгломерат проблем «людина-людське-людяність», то він є політичним антропологом. Якщо ж науковецьполітолог передусім сконцентрований навколо понять «держава-уряд-парламент-партія», то він є політичним інституціоналістом.

Політична антропологія народжувалась в руслі соціально-культурної антропології [22]. Саме до неї ми радимо політичним антропологам звертатись як до наукових витоків. Соціокультурна антропологія - це наука про суспільство та місце людини в суспільстві, вивчення яких відбувається через психокультурну контекстуалізацію. У монографії В. М. Мельника обгрунтувано антропологічний характер визначення Освальда Шпенглера-«Політика-це процес управління» [21, с. 215]. Отже, наше розуміння політичної антропології керується саме цією важливою вказівкою Шпенглера. Політична антропологія, як складова частина (субдисципліна) соціокультурної антропології повинна бути спрямована на розробку наукової теорії грамотного і планового державного управління. Отже, мета політичної антропології має державотворчий характер і відноситись до політичної антропології потрібно як до державницької ідеології. Ми визначаємо політичну антропологію як вчення про ідейний та ідеологічний розвиток традииійних форм політичного устрою в історичному процесі, що мають безпосередне відношення до сучасного стану політичної практики на рівні етносу та держави $[25$, с. $348-$ 349]. У статті «Традиціоналізм і політична антропологія» ми обгрунтували теорію позитивного та негативного політичного традиціоналізму. Ця теорія визначається наявністю на рівні етнічної психології роздвоєного відношення до держави та формального права, що визначається природно-географічними умовами історичного процесу [20, с. 125-126]. Ми також підкреслювали: «Формулою політичних антропологів має стати «традиціоналізм-фундаменталізмконсерватизм». Через ці категорії встановлюється політична традиція певного етносу протягом його етноісторії, етногенезу. У сукупності історико-політичних традицій окремих класів, станів, субетносів слід шукати спільний знаменник, через який можна провести аналогії між певними історико-політичними подіями. Поєднавши весь історичний, етноісторичний та етно- 
генетичний процеси у сітку аналогій, слід вивести найбільш придатні форми політичного розвитку того чи іншого етносу» [21, с. 546].Важливе значення для політичних антропологів має також книга Жоржа Баландьє «Політична антропологія», де було зроблено спробу застосувати політико-антропологічний аналіз до міжплемінних, міжнародних відносин [1].

Створення $i$ завдання Міжнародного иентру громадянської політології. Схожим чином прийнято розрізняти вчених-політологів і у середовищі Американської асоціації політичної та юридичної філософії, що спеціалізується на виробленні системи взаємодії між двома підходами та на усуненні того несприйняття, що панує у взаємовідносинах між науковцями обох зазначених категорій. Ми вбачаємо можливість оновлення та оживлення політичної науки саме в необхідності замирити антропологічний та інституційний підходи. Вважаємо, що для такого замирення необхідно підготувати грунт. Саме з цією метою (звісно ж, метою кінцевою) і було створено Міжнародний центр громадянської політології при Київському національному університеті імені Тараса Шевченка.

Як засновники Міжнародного центру громадянської політології, ми пропонуємо цілому політологічному співтовариству власне бачення теоретичної проблеми «кризи політичної науки» і свої (виходячи із власного наукового та освітнього досвіду) шляхи виходу з означеної кризи. Однак, це не означає, що наш погляд на боротьбу і взаємодію між «інституційним» і «антропологічним» $є$ єдино правильним. Ми повністю відкриті до фахової дискусії і своїми думками маємо на меті відкрити цю дискусію. Однак, маючи досвід досліджень і теоретизувань у сфері політичної антропології, зважаючи на тотальне засилля інституційного етатизму в сучасному українському науково-освітньому просторі, ми змушені констатувати, що у вітчизняному (та й у всьому пострадянському) контексті мова повинна йти не просто про інтеграцію антропологічного та інституційного підходів (як в США, РФ чи КНР), а про: по-перше-вироблення вчення про політичну антропологію на основі українських традицій культурно-цивілізаційного розвитку; по-друге - систематизацію і наукове обгрунтування існуючого інституційного підходу за умови його максимального роздержавлення; по-третє-термінологічне та методологічне розкриття того грунту, на якому ми збираємось замирити обидва підходи.

Громадянство як спільний знаменник антропологічного та інституційиого підходів. Отож, спочатку про грунт. Очевидно, що для того, щоб посилити наукову взаємодію між двома науками, підходами, практиками, потрібно, перш за все, відшукати спільний знаменник. В цьому контексті, антропологічний та інституційний підходи об'єднує, на наш погляд, найважливіша категорія у політичній науці-громадянство.

Громадянин-це людина політична, незалежно від власного відношення до політичних процесів. Навіть якщо громадянин демонструє поведінку абсинтеїста, він $є$ типовим homopoliticus, оскільки сам факт громадянства відображає сталий юридичний зв'язок у системі координат «людина-держава». Політична антропологія, досліджуючи взаємовідносини між людиною та державою також вважає громадянство тією сполучною силою, що має не лише головне значення для розбудови державності, але і глибоко проникає в структуру колективної свідомості кожної людини, що є водночас і громадянином.

Виходячи 3 теорії конституційного права, зазначимо, що людина і громадянин не $\epsilon$ категоріями тотожними. Однак, у публічній практиці будь-яка людина, що не відмовляється від активної чи навіть пасивної участі в справах конкретної громади, регіону, країни, співтовариства держав, насправді є громадянином. Громадянство-це феномен єднання людини з общиною та із землею, на якій ця община історично або тимчасово живе та розвивається. Таким чином, політико-антропологічний аналіз громадянства визначає його через географічний детермінізм (чи як навіть деякі вчені вже пишуть «через геолого-географічний детермінізм») та через етнопсихологічну зумовленість. Політична антропологія вбачає у громадянстві співвідношення географічного та психологічного факторів, що творить соціально чи національно свідому людину [25; 27; 28]. 
Інституційний підхід не бачить у громадянстві «природного» та «психологічного». Він звертає увагу передусім на державу, що розуміється як сукупність юридичних зв'язків між громадянами. Інституційний підхід використовує зазвичай традиційне визначення «громадянства» в юриспруденції: «Громадянство-це юридично визначений, стійкий, необмежений у просторі правовий зв'язок між особою і певною державою, що визначає їхні права та обов'язки» [17]. Просимо читачів звернути увагу на те, що у правничому розумінні громадянином $є$ навіть не людина, а «особа». Такий хід думок $є$ звичайним для етатизму. Людські взаємовідносини і взагалі вся сфера «людського» і «людяного» заміняється статистами на механіцизм. Ось чому інституційний підхід завжди краще міг полагодити із позитивістами, ніж з гегеліанцями чи релігійними філософіями. I це при тому, що гегеліанська школа в історико-правовій науці була представлена головним чином працями по історії державних інституцій, закладів, урядів, а політична історія розумілась як генеалогія керівної верхівки тієї чи іншої держави.

Громадянство-це один із вимірів людського. Не більше і не менше. А це значить дуже багато! Передусім те, що людина як біосоціальна істота, що здатна вступати у взаємодію із природними силами, створювати антрополандшафт і через перманентний стан праці змінювати геоландшафт, є творцем і співвласником тієї держави, що охоплює терени іії геолокації [3; 7; 10]. Отже, громадянин $є$ співзасновником, співвласником і невідчужуваною основою своєї держави. В цьому, на наш погляд, лежать витоки демократії і як ідеології, і як форми правління. В цій же системі координат знаходиться і юридичний термін «соціальна держава». Держава $\epsilon$ соиіальною саме тодi, коли вона орієнтована на свойх людей-на громадян.

Отже, навіть у сухій формальній юриспруденції мову потрібно вести не про якусь ефемерну «особу», а про ту біосоціальну істоту, що забезпечує економічний розвиток, інтелектуальні спроможності та навіть здатна вступати у двобій із силами природи - про «людину».

Антропос-це категорія з усіма плюсами та мінусами, що притаманні будь-якій смертній істоті. Людина має забагато слабкостей і держава багато в чому покликана створити ефективний регулятор для усунення цих слабкостей із соціального простору як шкідливих «спільній справі». Поза людиною неможливо створити державу. Держава не може функціонувати без людини. Вся система державного управління з точки зору політичної психології існує для двох речей: а) або на культивацію позитивного і динамічного розвитку людських спроможностей, талантів, на успішну самореалізацію своїх громадян поряд із контролем над ії біофізіологічною сутністю; б) або виключно на пригнічення інстинктивної природи людин, що, в свою чергу, завжди викликає посилену реакцію у відповідь.

Ми повинні усвідомити, що людина-ие інтегративний інститут. Ї̈̈ природа всевмісна [31]. Будучи головним предметом філософії, соціальних та гуманітарних наук, людина набуває гіперзначення для політики як процесу і стану. Людина в політиці здатна проявити як усі свої позитивні, так і всі свої негативні якості. Вона інтегрує все хороше і все погане. Отже, важливою проблемою для психологічних наук залишається потреба дезавуювати вплив негативних чинників соціального співжиття на громадянина як людину політичну.

Римське право, проблема громадянства і общинний демократизм слов'ян. Сучасна юриспруденція бере свій початок з римського права. До нашого часу, завдяки знаменитим візантійським кодифікаціям законодавчих актів (у першу чергу, завдяки кодифікаціям Юстиніана) найкраще збереглось римське цивільне право, що як предмет навіки закріпилось у навчальних програмах усіх вищих навчальних закладів юридичного профілю. Римське цивільне право перетворилось у своєрідну легенду, що активно використовується і пропагується європейськими політиками задля обгрунтування власної відвічної спільності у царині права. Римське цивільне право багатьма визнається головним цивілізаційним надбанням Європи в юридичній сфері та навіть у сфері економічних відносин, внаслідок свого формального закріплення права приватної власності. Багато хто з сучасних українських істориків дивиться на право приватної власності як на певну «чарівну паличку». Мовляв, якщо воно $\epsilon$ - то досліджувана культура належить заходу. Якщо ж його немає, то вона є східною. Така постановка питання, на наш погляд, 
$\epsilon$ не тільки некоректною, але і шкідливою. Право приватної власності з'явилось у більшості європейських народів лише на межі I і II тисячоліть нашої ери, внаслідок поступового сприйняття германськими володарями візантійських правил гри і внаслідок укладення політичних домовленостей між Папами Римськими і німецькими імператорами [2; 4].

I германці, і слов'яни завжди орієнтувались на общинне землеволодіння. Германці вступили раніше у взаємодію з Римом і засвоювали приватну власність дуже довго. Слов'яни переймали іiї переважно від візантійців. Так було і з українцями. Однак, ані в українців, ані у сербів, ані у хорватів, ані у болгар, тривалі контакти з візантійцями, прийняття християнства, анітрохи не підірвали авторитету общини. По суті, цей авторитет зберігається і сьогодні. На Балканах він навіть розповсюджується на общинну землевласність, що є яскраво вираженою економічною традицією. Особливо цікавим є сербохорватський приклад. Його досліджував ще Ю. Бромлей. Радимо також ознайомитись із його думками 3 приводу взаємодії між категоріями «етносродина-громадянство».

Напевно, що досі найповніше і найдоступніше проблематика традиціоналізації общинної землевласності проаналізована I. М. Смірновим (1856-1904) у книзі «Очерк истории Хорватского государства до подчинения его Угорской короне» (1879), де він пише: «югославська родина загалом, а особливо родина хорватська (ми мусимо розуміти, що це визначення багато в чому слід розповсюдити на весь ареал розселення слов'ян в другій половині I тисячоліття нашої ери-Ф. К., В. М. ), представляла собою особливий тип у порівнянні з тими, які ми помічаємо в античних народів та народів германських. Сім'я тут не знаходиться в безумовній залежності від батька сімейства і останній не має права розпоряджатись не тільки життям та смертю своїх домочадців, але навіть і їхнім майном. Письмові пам'ятки, що дійшли до нас від IX-XI століть, дають нам можливість довести це положення головним чином у сфері майнових відносин. У хорватській родині цього періоду панує повна рівноправність усіх ії членів. Дідина (земля, на якій проживає сім’я) вважається спільною власністю. Родина обробляє свою землю спільно та живе нею. Без сильної необхідності сімейна власність рідко відчужувалась. Якщо обставини вимагали відчужування, то батько сімейства повинен був отримати дозвіл домочадців (усіх! — Ф. К., В. М. ) і тільки після їхньої згоди здійснити відчуження» [29, с. 98]. О. Воропай у своєму фундаментальному дослідженні присвяченому звичаям українського народу багато в чому підтверджує тезу про наявність відголосків аналогічного явища i в східнослов'янському середовищі. Перехід від общинного землеволодіння до приватного права лише після християнізації спостерігається у ранньопольських племен. До наших днів повністю не позбулись общинного землеволодіння балканські слов'яни (психологічно). І. М. Смірнов навіть писав, що право голоса в родині мали всі жінки [29, с. 99]. Виключні права жінки мали і в давньоруському суспільстві, на відміну від спільнот античних (грецьких, римських) та германських. Вся ця цивільно-правова проблематика, питання про перехід від общинного до приватного землеволодіння свідчить про наявність у слов'ян власної відособленої від інших племен політичної культури, що від самого початку грунтувалась на повазі до общини, повазі до старших, общинній правоздатності всіх членів родини, залученні жінок до вирішення усіх суспільних проблем.

Отож, українці, білоруси, поляки, серби, хорвати, словенці, болгари, словаки та інші слов'янські нації мають віковічні традиції демократичного соціального устрою. Можливо, що така тотальна демократизація навіть виступала одним із серйозних деструктивних, а не позитивних чинників у нашій історії. Про це, зокрема, писав і М. Ю. Брайчевський [5]. Однак, разом із тим, ми підкреслимо, що наявність свого права, своїх традицій суду, своїх традицій обрання влади ще в X столітті, свідчить про наявність політичної культури такого рівня, який дозволяє нам і сьогодні вважати себе одними із найдемократичніших націй-політично, психологічно, економічно.

Римське публічне право дійшло до нас в набагато меншому обсязі, аніж римське приватне право. Воно пройшло забагато етапів трансформацій i, по суті, відображає не стільки право 
Давнього Риму, скільки пізніші нашарування Візантійської імперії, Священної Римської імперії германської нації та місцевих державних утворень. Римське публічне право-це «трансформат». Однак, це не означає, що його не потрібно досліджувати. Саме виходячи з наявних праць, ми маємо уявлення про CivitasRomana-римське громадянство. Вивчити і дослідити сутність інституту громадянства в Римській імперії як інституту соціального, інституту юридичного та інституту римської державності взагалі-надважливе завдання для всіх, хто займається проблематикою обгрунтування громадянства (чи то в юридичному, чи то в політологічному, чи то у філософському аспектах).

«Квіріти» або ж громадяни Риму були найвищим класом свого суспільства. Від часів появи Римської республіки і майже до I століття до нашої ери (аж до часів імператорських узурпацій) комплекс прав римських громадян складався із: 1) права голосувати у народних зборах; 2) «права честі» - права військової і громадянської служби; 3) комерційного права, що дозволяло мати приватну власність і вкладати контракти; 4) право на повністю легальний шлюб; 5) відсутність необхідності виконувати норми будь-якого іншого місцевого (провінційного, варварського) права; 6) право суду і судових позовів; 7) право міграції; 8) право на незастосування щодо громадянина тортур і смертної кари [2].

Римське право творило свою приватну і публічну традиції, поняття про громадянства, засновуючись на традиціях центральноіталійських племен, які практикували приватну власність та соціальну нерівність ще 3 етруських часів. 3 огляду на повідомлення Геродота про скіфів і 3 огляду на сучасні дослідження В. Ю. Мурзіна (особливо слід відзначити його монографію «Скифская проблема глазами автора», 2014) можна також зазначити, що скіфо-сарматський світ (в тому числі і скіфи-хлібороби) виходили із права общинної землевласності та соціальної рівності за родинною ознакою [26]. Це означає, що протослов'янський і протоєвропейських світи ще в своєму зародковому стані відізнялись своїми правовими традиціями, що свідчить про їхню культурно-цивілізаційну відокремленість. Так чи інакше, але ми вважаємо, що у слов'ян існує незаперечне історичне право називати себе демократичними націями, на відміну від, скажімо, німців, італійців чи англійців.

Те поняття демократії, що пізніше було сформульоване класиками світової політичної думки, в тому числі на основі осмислення ними джерел римського права, в його найбільш концептуальній формі, із забезпеченням тотальної рівності всіх членів общини, із формування протодержав саме на платформі общин і родів, найперше в Свропі проявилось саме у слов'ян. Сучасний сербохорватських общинний демократизм (його, до речі, місцеві політологи вже давно тлумачать як «консерватизм»), досліджуваний Бромлеєм і Алєксєєвим, є нічим іншим, як реліктом давнього демократизму загальнослов'янського [8].

Сьогодні ми зобов'язані звернути нашу увагу на коріння - в тому числі на коріння нашого політичного устрою. Ми повинні віднайти можливість об'єднати інституційний і антропологічний підходи на кшталт найбільш успішних практик об'єднання римського поняття про громадянство із слов'янським общинним демократизмом. Між іншим, у світоглядній несумісності останніх категорій криється основна причина сучасної кризи української політичної науки і сучасного наростання безідейного, але ідеологізованого етатизму. Община завжди звертала увагу на людину. А ми - політологи як теоретики державності, маємо повернути наші погляди і на людину, і на локальну общину.

Взяти все найкраще у античних і середньовічних спільнот та спробувати на цій основі витворити новий шлях - ця теза звучить спокусливо для кожного вченого-гуманітариста. Зізнаємось, що вона захоплює і нас. Однак, інколи потрібно задуматись і над тим, що свій шлях вже існує, що він знаходиться у нас в полі видимості, а ми його просто не бачимо. Іван Смірнов у монографії «Очерк истории Хорватского государства до подчинения его Угорской короне» писав, що головне для історичного розвитку державності-зробити правильний культурно-цивілізаційний вибір. Він досить детально розбирає це твердження на прикладі римо-католицької орієнтації першого хорватського короля Томіслава Великого (914-940), вважаючи його відмову від орто- 
доксії та геополітичної дружби із Візантією головною причиною подальшого занепаду Хорватії під ударами угорців (в 1091-1102 роках) [29]. Ми ж підкреслимо, що наукове осмислення феномену громадянства у поєднанні з його общинною прив'язкою може дати нам величезний матеріал для роздумів, розбити існуючі стереотипи і дати уявлення саме про той існуючий власний політичний шлях.

Західна традиція громадянства пройшла ряд важливих етапів у своєму процесі становлення: Общину, Поліс, Середньовіччя, Відродження. Остаточно, із врахуванням досвіду римського права, воно викристалізувалось в епоху Просвітництва, коли було сформульовано вчення про демократію як про вищу політичну ідею, що грунтується на засадах прав і свобод людини. Вже потім, із теоретичних систем обгрунтування демократії, теорія прав і свобод людини перейшла в науку конституційного права - галузь юриспруденції.

Людина у громадянині чи громадянин в людині? Людина як громадянин формувалась в процесі переходу людини від дикої стадії існування до осілого життя. На ії общинному, а згодом і державному житті (вірніше навіть на їі участі в цьому житті) дуже сильно відбився психологічний конфлікт між свідомим і несвідомим, що в народному світогляді часто відображався як конфлікт «між добром і злом». Боротьба інстинктів проти моральних норм супроводжувала весь процес політичної еволюції суспільств від первісного ладу і до сьогодні. Не оминула вона і громадянства, що значною мірою було покликане примирити інстинктивну природу біосоціальної істоти - людини із iï фізіологічними потребами. Одержавлення через інститут громадянства має для людей важливе психологічне значення-воно забезпечує пригнічення відвічного страху за життя, акумулює інстинкти самозбереження і харчування, що пояснюється наявністю сталого зв'язку людини та суспільства.

\section{4. Висновки}

Постановка нашої проблеми лежить передусім в наступному контексті: а чи не пригнічує держава, в тому числі і через формально-правові інститути, поряд із страхом, комплексами та негативними сторонами інстинктивної природи також і позитивні прояви людського в людині? Наше завдання абсолютно антропологічне-ми, як науковці-гуманітарії, мусимо розібратись у тому, щзо ж знаходиться в самій людині-людині політичній? Ось чому нам так необхідно антропологізувати політологію. Ось навіщо ми створили наш Міжнародний центр громадянської політології. Ось чому ми повинні обмежити етатизм - надмірна інституціоналізація вкупі із заміною держави людської на державу бюрократичну має наслідком втрату людського обличчя та його механізацію.

\section{5. Список літератури:}

1. Баландьє Жорж. Політична антропологія / Жорж Баландьє.—Київ: Альтерпрес, 2002. - $252 \mathrm{c}$.

2. Бартошек М. Римское право: понятия, термины, определения / Милан Бартошек.- М.: Юридическая литература, 1989.—448 с.

3. Берг Л.С. Климат и жизнь / Л. С. Берг.-М., 1947.-196 с.

4. Быстренко В.И. История государственного управления и самоуправления в России / В. И. Быстренко. - Новосибирск-Москва: Издательство Новосибирской государственной академии экономики и управления, 1997.—92 с.

5. Брайчевський М. Ю. Суспільно-політичні рухи в Київській Русі / М. Ю. Брайчевський. Вибране. Т. 1.—К.: Видавництво імені Олени Теліги, 2009.—720 с.

6. Вівчарик М. М. Україна: від етносу до нації / М. М. Вівчарик.-Київ: Вища школа, 2004. - 239 c.

7. Гумилев Л.Н. О соотношении природы и общества согласно данным исторической географии и этнологии / Л. Н. Гумилев. // Вестник Ленинградского Государственного Университета. — 1970.—№ 24.-С. 39-49. 
8. Гумилев Л. Н. Этногенез и биосфера Земли / Л. Н. Гумилев-М.: Айрис-пресс, 2012. $-560 \mathrm{c}$.

9. Данилюк І.Етнічна психологія як галузь наукового знання: історико-теоретичний вимір / І. Данилюк.—К., 2010.—432 с.

10. Дерягина М. А. Эволюционая антропология: биологические и культурные аспекты / М. А. Дерягина.-М., 2003.-208 с.

11. Камінський А. С. Історія Речі Посполитої як історія багатьох народів, 1505-1795. Громадяни, їхня держава, суспільство, культура / А. С. Камінський. - Київ: Наш час, 2011. - 263 c.

12. Кикешев Н. И. Истоки славянской цивилизации / Н. И. Кикешев.-М.: ИРЦ, 2016. - $912 \mathrm{c}$.

13. Кирилюк Ф. М. Політологія Нової доби / Ф. М. Кирилюк.-К: Академія, 2003.- 254 с.

14. Кирилюк Ф. М. Філософія політичної ідеології / Ф. М. Кирилюк.—К.: Центр учбової літератури, 2009. - 520 с.

15. Кирилюк Ф. М. Новітня політологія / Ф. М. Кирилюк. - К.: Центр учбової літератури, 2009. - 564 с.

16. Кирилюк Ф. М. Неопатримоніалізм: історія, теорія, практика / Ф. М. Кирилюк.—К.: ВАДЕКС, 2014. - $553 \mathrm{c}$.

17. Кириченко С. О. Громадянське суспільство і правова держава: поняття та зміст / С. О. Кириченко.—К.: Логос, 1999.—45 с.

18. Крадин Н. Н. Политическая антропология / Н. Н. Крадин.-М.: Логос, 2004. - 270 с.

19. Мамут Л. С. Этатизм и анархизм как типы политического сознания: домарксистский период / Л. С. Мамут.-М.: Наука, 1989.—255 с.

20. Мельник В. М. Традиціоналізм і політична антропологія / В. М. Мельник // Науковий вісник Міжнародного гуманітарного університету. Серія: Історія. Філософія. Політологія. Збірник наукових праць.-Одеса: Фенікс, 2014. - Випуск №8.—С. 123-127.

21. Мельник В. М. Нариси з теорії соціокультурної антропології / В. М. Мельник.—Вінниця: ТОВ «Вінницька міська друкарня», 2015.—552 с.

22. Melnyk V. M. Ethnopolitical Essays / V. M. Melnyk. — Saarbrucken: Lambert Academic Publishing, 2016. - 74 pp.

23. Мельник В. М. Етноісторичні аспекти становлення польської нації (Рання етнічна історія поляків) / В. М. Мельник.-Вінниця: Друкарня ВНМУ ім. М. І. Пирогова, 2016. — 44 с.

24. Мельник В. М. Бутан: правовий контекст модернізації / В. М. Мельник.-Вінниця: Друкарня ВНМУ ім. М. І. Пирогова, 2016. - 55 с.

25. Мельник В. М. Теоретична конструкція політичної антропології / В. М. Мельник // Гілея: науковий вісник. Збірник наукових праць.—К.: Видавництво «Гілея», 2016. — Випуск 113 (10). - С. 348-360.

26. Мурзин В. Ю. Скифская проблема глазами автора / В. Ю. Мурзин. - К.: Видавець Олег Філюк, 2014. - 120 с.

27. Петрушенко Е. Ф. Значение этнической психологии в антропологической теории / Е. Ф. Петрушенко, В. М. Мельник // Science, Technology and Life - 2014: Proceedings of the international scientific conference. Czech Republik, Karlovy Vary, 27-28 December 2014 / Editors V. A. Iljuhina, V. I. Zhukovskij, N. P. Ketova, A. M. Gazalieva, G. S. Mal. Electron. txt. d. (13,3 MB). Karlovy Vary: Skleneny Mustek; MCNIP, 2015._Pp. 1063-1071.

28. Проценко О. Походження свободи. Осмислення витоків та розвитку концепції громадянського суспільства / О. Проценко, В. Чепинога. - К.: Смолоскип, 1996. - 140 с.

29. Смирнов И.Н. Очерк истории Хорватского государства до подчинения его Угорской короне / И. Н. Смирнов. - М.: Книжный дом «Либроком», 2016. - 136 с.

30. Соловьев С. М. Наблюдения над исторической жизнью народов / С. М. Соловьев. - М.: Астрель, 2003. - 511 с. 
31. Фромм Э. Вы будете как Боги / Э. Фромм. - М.: АСТ, 2013.-413 с.

32. Шмитт К. Политическая теология / К. Шмитт. - М.: Канон-Пресс-Ц, 2000._-333 с.

\section{References:}

1.Baland'ie Zhorzh. Politychna antropolohiia / Zhorzh Baland'ie. - Kyiv: Al'terpres, 2002. - $252 \mathrm{~s}$.

2. Bartoshek M. Rymskoe pravo: poniatyia, termyny, opredelenyia / Mylan Bartoshek. - M.: Yurydycheskaia lyteratura, 1989. - 448 s.

3. Berh L. S. Klymat y zhyzn'/ L. S. Berh.—M., 1947.—196 s.

4. Bystrenko V.Y. Ystoryia hosudarstvennoho upravlenyia y samoupravlenyia v Rossyy / V. Y. Bystrenko. - Novosybyrsk-Moskva: Yzdatel'stvo Novosybyrskoj hosudarstvennoj akademyy ekonomyky y upravlenyia, 1997._-92 s.

5. Brajchevs'kyj M. Yu. Suspil'no-politychni rukhy v Kyivs'kij Rusi / M. Yu. Brajchevs'kyj. Vybrane. T. 1.-K.: Vydavnytstvo imeni Oleny Telihy, 2009.—720 s.

6. Vivcharyk M. M. Ukraina: vid etnosu do natsii / M. M. Vivcharyk. - Kyiv: Vyscha shkola, 2004. - $239 \mathrm{~s}$.

7. Humylev L. N. O sootnoshenyy pryrody y obschestva sohlasno dannym ystorycheskoj heohrafyy y etnolohyy / L. N. Humylev. // Vestnyk Lenynhradskoho Hosudarstvennoho Unyversyteta. - 1970. — № 24. — S. 39-49.

8. Humylev L. N. Etnohenez y byosfera Zemly / L. N. Humylev-M.: Ajrys-press, 2012. - 560 s.

9. Danyliuk I. Etnichna psykholohiia iak haluz' naukovoho znannia: istoryko-teoretychnyj vymir / I. Danyliuk. - K., 2010.—432 s.

10. Deriahyna M.A. Evoliutsyonaia antropolohyia: byolohycheskye y kul'turnye aspekty / M.A. Deriahyna.-M., 2003. - 208 s.

11. Kamins'kyj A. S. Istoriia Rechi Pospolytoi iak istoriia bahat'okh narodiv, 1505-1795. Hromadiany, ikhnia derzhava, suspil'stvo, kul'tura / A. S. Kamins'kyj.—Kyiv: Nash chas, 2011. - 263 s.

12. Kykeshev N. Y. Ystoky slavianskoj tsyvylyzatsyy / N. Y. Kykeshev.—M.: YRTs, 2016. - $912 \mathrm{~s}$.

13. Kyryliuk F. M. Politolohiia Novoi doby / F. M. Kyryliuk. —K: Akademiia, 2003.- 254 s.

14. Kyryliuk F. M. Filosofiia politychnoi ideolohii / F. M. Kyryliuk. - K.: Tsentr uchbovoi literatury, 2009. - $520 \mathrm{~s}$.

15. Kyryliuk F. M. Novitnia politolohiia / F. M. Kyryliuk. - K.: Tsentr uchbovoi literatury, 2009. - 564 s.

16. Kyryliuk F. M. Neopatrymonializm: istoriia, teoriia, praktyka / F. M. Kyryliuk. - K.: VADEKS, 2014. - $553 \mathrm{~s}$.

17. Kyrychenko S. O. Hromadians'ke suspil'stvo i pravova derzhava: poniattia ta zmist / S. O. Kyrychenko.—K.: Lohos, 1999.—45 s.

18. Kradyn N. N. Polytycheskaia antropolohyia / N. N. Kradyn. —M.: Lohos, 2004.—270 s.

19. Mamut L. S. Etatyzm y anarkhyzm kak typy polytycheskoho soznanyia: domarksystskyj peryod / L. S. Mamut._M.: Nauka, 1989.—255 s.

20. Mel'nyk V.M. Tradytsionalizm i politychna antropolohiia / V. M. Mel'nyk // Naukovyj visnyk Mizhnarodnoho humanitarnoho universytetu. Seriia: Istoriia. Filosofiia. Politolohiia. Zbirnyk naukovykh prats'.-—Odesa: Feniks, 2014. — Vypusk №8. - S. 123-127.

21. Mel'nyk V. M. Narysy z teorii sotsiokul'turnoi antropolohii / V. M. Mel'nyk. — Vinnytsia: TOV «Vinnyts'ka mis'ka drukarnia», 2015. - 552 s.

22. Melnyk V. M. Ethnopolitical Essays / V. M. Melnyk. — Saarbrucken: Lambert Academic Publishing, 2016. - 74 pp. 
23. Mel'nykV. M. Etnoistorychni aspekty stanovlennia pol's'koi natsii (Rannia etnichna istoriia poliakiv) / V. M. Mel'nyk. - Vinnytsia: Drukarnia VNMU im. M. I. Pyrohova, 2016. — 44 s.

24. Mel'nyk V. M. Butan: pravovyj kontekst modernizatsii / V. M. Mel'nyk. — Vinnytsia: Drukarnia VNMU im. M. I. Pyrohova, 2016. - 55 s.

25. Mel'nyk V. M. Teoretychna konstruktsiia politychnoi antropolohii / V. M. Mel'nyk // Hileia: naukovyj visnyk. Zbirnyk naukovykh prats'.—K.: Vydavnytstvo «Hileia», 2016. — Vypusk 113 (10). - S. 348-360.

26. Murzyn V. Yu. Skyfskaia problema hlazamy avtora / V. Yu. Murzyn. - K.: Vydavets' Oleh Filiuk, 2014. - $120 \mathrm{~s}$.

27. Petrushenko E. F. Znachenye etnycheskoj psykholohyy v antropolohycheskoj teoryy / E. F. Petrushenko, V. M. Mel'nyk // Science, Technology and Life - 2014: Proceedings of the international scientific conference. Czech Republik, Karlovy Vary, 27-28 December 2014 / Editors V. A. Iljuhina, V. I. Zhukovskij, N. P. Ketova, A. M. Gazalieva, G. S. Mal. Electron. txt. d. (13,3 MB). Karlovy Vary: Skleneny Mustek; MCNIP, 2015.—Rp. 1063-1071.

28. Protsenko O. Pokhodzhennia svobody. Osmyslennia vytokiv ta rozvytku kontseptsii hromadians'koho suspil'stva / O. Protsenko, V. Chepynoha._K.: Smoloskyp, 1996.—140 s.

29. Smyrnov Y.N. Ocherk ystoryy Khorvatskoho hosudarstva do podchynenyia eho Uhorskoj korone / Y. N. Smyrnov.—M.: Knyzhnyj dom «Lybrokom», 2016.—136 s.

30. Solov'ev S. M. Nabliudenyia nad ystorycheskoj zhyzn'iu narodov / S. M. Solov'ev. - M.: Astrel', 2003. - 511 s.

31. Fromm E. Vy budete kak Bohy / E. Fromm. - M.: AST, 2013.—413 s.

32. Shmytt K. Polytycheskaia teolohyia / K. Shmytt.—M.: Kanon-Press-Ts, 2000.—333 s. 